\title{
Variability of Morphological Characteristics of Hedysarum grandiflorum (Fabaceae, Dicotyledones) in Various Ecological Conditions of the Southern Volga Upland
}

\author{
Michail V. Lavrentiev, https://orcid.org/0000-0003-3241-2133; mihaillavrentev@yandex.ru \\ Vladimir A. Boldyrev, https://orcid.org/0000-0002-3323-0537; boldyrev52@bk.ru
}

\author{
Saratov State University \\ 83 Astrakhanskaya St., Saratov 410012, Russia
}

Received 25 February 2019, revised 17 March 2019, accepted 21 April 2019

Lavrentiev M. V., Boldyrev V. A. Variability of Morphological Characteristics of Hedysarum grandiflorum (Fabaceae, Dicotyledones) in Various Ecological Conditions of the Southern Volga Upland. Povolzhskiy Journal of Ecology, 2019, no. 4, pp. 445-457. DOI: https://doi.org/10.35885/16847318-2019-4-445-457

This article is an open access article distributed under the terms and conditions of the Creative Commons Attribution 4.0 License

In recent decades the interest to the study of Hedysarum has increased. Researchers touched upon the classical issues of morphology and variability of external features of Hedysarum grandiflorum and other species of Hedysarum (to clarify morphology, to more accurately separate existing species, to describe the morphology of new species, including rare ones) providing almost no detailed descriptions. The paper provides information about the morphology of external features of $H$. grandiflorum in the Southern Volga Upland. The study was conducted in 2007-2018. We have studied $23 \mathrm{H}$. grandiflorum cenopopulations in habitats with various environmental conditions, where more than 600 counting sites were laid, and concluded that the morphological features of $H$. grandiflorum are rather variable and the values of morphometric parameters are higher in the northeastern part of the study area. The well-being of the population is achieved due to some heterogeneity in the size of individual plants and by means of suppressing the growth and size of separate cenopopulations. The decrease in the parameters of signs is often associated with a higher anthropogenic load. Dimensional indicators of individuals from the cenopopulations of the species studied depend on the thickness of soil, which decreases from fescue-feather grass to petrophyte steppes. Cluster analysis has allowed us to divide the cenopopulations into southern, northern and northeastern ones, and those with anthropogenic impact. The least variable and most informative morphological features of $H$. grandiflorum (in the descending order of importance) are: the length of the standard, the diameter of the caudex, the plant height, the number of foliole pairs, the number of inflorescences, the number of leaves, the length of the unpaired foliole, the number of flowers on the inflorescence, the length of leaves and the width of the unpaired foliole. In the overwhelming majority of the plants encountered, all the petals of the corolla were of uniform light yellow color, turning into a white tint to the edges of the petals. In some cenopopulations, the corolla can be colored differently and unevenly, especially at the keel. Approximately $0.3 \%$ of individuals of the corolla petals and/or the lower part of the keel and/or veins are light blue or light pink, less than $0.07 \%$ has a light magenta or even light purple tint of the veins of the carina, edges of the petals or the whole corolla. Similar individuals are found in other regions. Many scientists noted this peculiarity a long time ago and had already described this phenomenon as a color variation (for example, H. grandiflorum var. violaceum) or less often, as a subspecies (for example, $H$. grandiflorum ssp. argenteum). Individuals with recessive coloring of the corolla from the area of study are called intraspecific color variations.

Keywords: Hedysarum grandiflorum, Hedysarum, morphology, variability, corolla coloring, Volga Upland.

(C) Lavrentiev M. V., Boldyrev V. A., 2019 


\section{INTRODUCTION}

When working with rare plant species, using morphometric methods can be significant in obtaining information about the biology of their local populations (Zlobin et al., 2013). Such an approach allows us to avoid any impact on individuals while studying protected species, such as Hedysarum grandiflorum Pallas, 1773 - calciphilous everlasting taproot caudex polycarpic, listed in the Red Books of the Russian Federation (2008) and the Saratov region (2006) with category 3 and the status of the rare species, recommended for inclusion in the next edition (Arkhipova et al., 2016). In addition, we need to study and clarify the features that are informative for the taxonomy of the genus Hedysarum and determination of the viability of the $H$. grandiflorum cenopopulations according to the previously proposed criteria (Lavrentiev, $2016 a$; Lavrentiev, Boldyrev, 2017).

In recent decades the interest to the study of Hedysarum has increased. Researchers touched upon the classical issues of morphology and variability of external features of H. grandiflorum (Ilyina, 2005, 2006; Avdeyev, Ryazanova, 2008; Lavrentiev, 2016 b; Suprun, Schanzer, 2017) and other species of Hedysarum (clarified morphology (Zubairova, Anatov, 2012; Belous, Zinner, 2013; Syeva, Mandaeva, 2013; Zhmud, 2013; Dural, Citak, 2015), existing species are more accurately separated (Zvyagina et al., 2016), describes the morphology of new species (Bidarlord et al., 2015; Dehshiri, Goodarzi, 2016; Liu et al., 2017; Başköse et al., 2018; Liu et al., 2019 a; Nafisi et al., 2019), including rare ones (Haidar, Qaiser, 2018)) and providing no detailed descriptions (Golovanov et al., 2018; Abbas et al., 2019). The information for full and clear separation of species, subspecies and hybrids of the intricate genus Hedysarum has not been gathered so far. To resolve this issue, the use of chemotaxonomy has begun (Huang et al., 2019; Liu et al., $2019 \mathrm{~b}$ ), but despite this, the use of morphology is mandatory to eliminate errors in the description of new species (Arigela, Singh, 2018). In addition, morphology is taken into account when studying ontogenesis and life forms (Karnaukhova, 2015), diagnostics of the state of populations (Zubairova, 2015; Abramova et al., 2019), restore populations (Maslova et al., 2019) and phytocenoses (Wu et al., 2019). Changes in morphological and anatomical features are used when studying the adaptation of species to new conditions (Erst et al., 2014; Portnyagina et al., 2014; Zhmud, 2014; Karnaukhova, 2016; Zhmud et al., 2018; Karnaukhova et al., 2018; Tonguç et al., 2019).

The territory of the study area is located between the Volga and the Medveditsa rivers and stretches from the northern to the southern border of the Saratov region. The need for this study was determined by the diversity of natural environment of the territory and the presence of significant areas of immature humus-carbonate soils and outcrops of carbonate rocks in the study area, which create very peculiar edaphic and microclimatic conditions leading to the formation of plant communities, different from zonal vegetation (Arkhipova et al., 2017).

The aim of the work was to study the morphological features of $H$. grandiflorum and its variability and phytocenotic plasticity in the southern Volga Upland in the admin- 


\section{VARIABILITY OF MORPHOLOGICAL CHARACTERISTICS}

istrative borders of the Saratov region. This article supplements the information received earlier (Lavrentiev, 2018).

\section{MATERIAL AND METHODS}

The object of the study was the cenopopulations (C) of the H. grandiflorum Pall. located in the southern Volga Upland in the administrative boundaries of the Saratov region (Fig. 1).

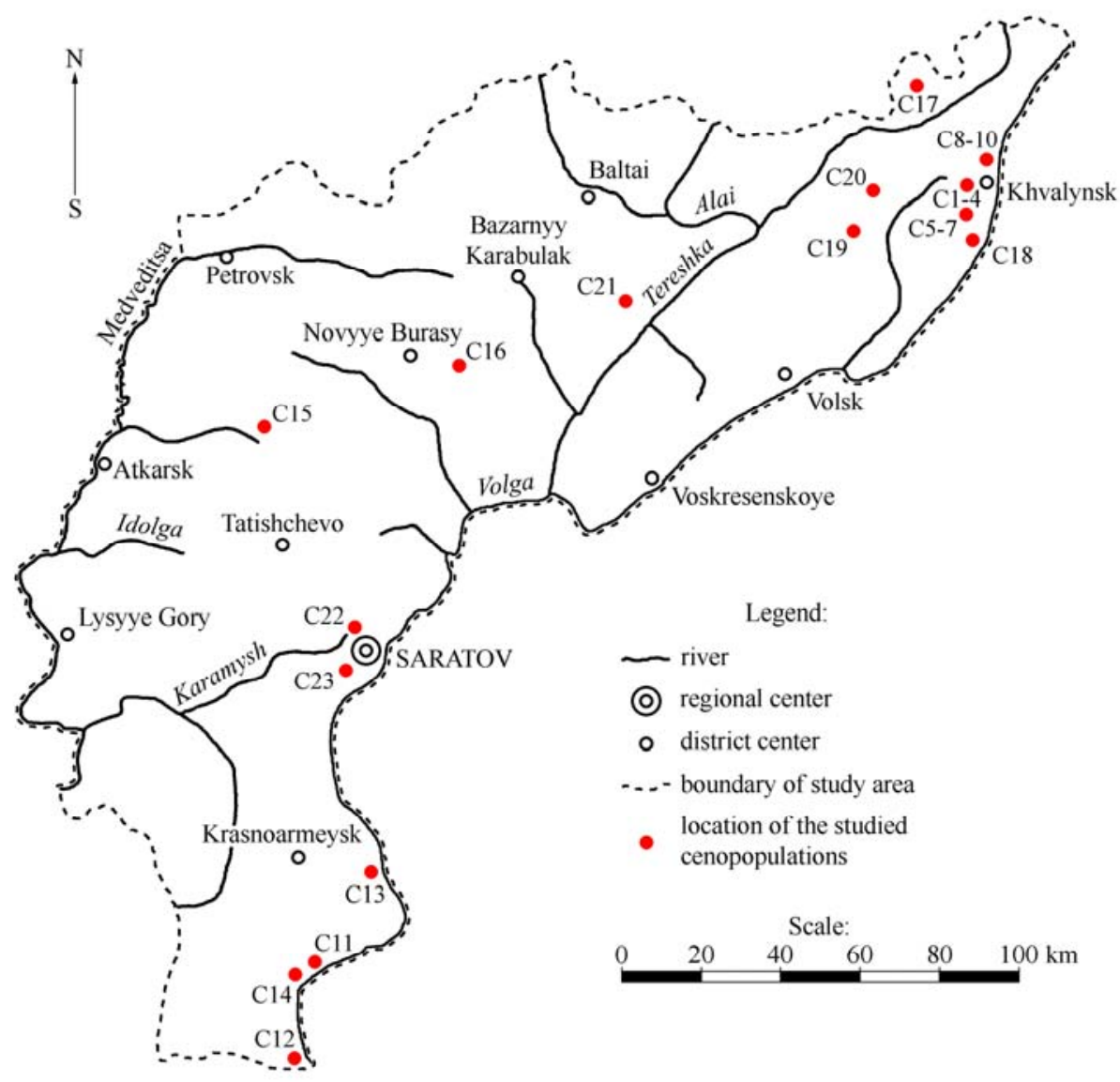

Fig. 1. Schematic map of the study area (according to Lavrentiev, Boldyrev (2017) with modifications)

The study was conducted in 2007-2018. 23 H. grandiflorum cenopopulations in habitats with various environmental conditions, in which more than 600 discount area were laid, were studied in detail. Over the period of our study, we described more than 3600 individuals of the species and measured about 67150 of them. Detailed description of the 
studied habitats and cenopopulations are presented in the dissertation of M. V. Lavrentiev (2018).

Anthropogenic load was determined by the route method. Comprehensive accounting of various qualitative and quantitative objects was carried out: changes in microrelief, disturbances of soil and grass vegetation, artificial reservoirs and streams, disturbances of woody vegetation and individual trees, the presence of stationary anthropogenic objects, household trash lying on the ground and meetings of synanthropic animals. For qualitative objects representation was expressed in shares of the total length of the route, and for quantitative objects - in units per $1 \mathrm{~km}^{2}$ of the route.

The following morphological parameters are described in each individual H. grandiflorum of an mean generative ontogenetic state: the plant height, the number of leaves, the length of the leaves, the number of pairs of foliole (including unpaired), the length and the width of unpaired foliole, the number of inflorescences, the number of flowers on the inflorescence, the length of the standard and the diameter of the caudex. Statistical processing of the research results was carried out in accordance with the universally accepted methods using the integrated system «Statistica» version 6.0 and Microsoft Office Excel 2003. Comparison of indicators was carried out according to parametric criteria, using the Fisher LSD $(F$-test $)$. For each parameter, the formulas were used to determined the arithmetic mean $(X)$, arithmetic mean error $\left(S_{x}\right)$ and the coefficient of variation $\left(C_{V}\right)$. For parameters was determined the coefficient of phytocenotic plasticity $\left(I_{p}\right)$ (Zlobin et al., 2013):

$$
I_{p}=\frac{\left(x_{\max }-x_{\min }\right)}{x_{\max }},
$$

where $x_{\max }$ - maximum value of the parameter, $x_{\min }$ - minimum value of the parameter.

Variability of parameters is estimated by coefficient of variation, and plasticity - by phytocenotic plasticity. When estimating the amplitude of the parameters variability, an empirical scale of the levels of variability of morphometric parameters was used, developed by S. A. Mamaev (1970). When constructing a cluster, we used the algorithm of weighted Euclidean distance based on pair-group method using arithmetic averages. To identify the dynamics of the relationship existing between the analyzed parameters and indicators, correlation analysis was used, and only significant correlation relationships were taken into account $(p<0.05)$.

\section{RESULTS}

The average values of features in the studied cenopopulations vary greatly, therefore, detailed data on all cenopopulations are presented in the dissertation of M. V. Lavrentiev (2018). Mean values of features and their variability are shown in the Table.

Cluster analysis on average morphometric parameters identified several groups and subgroups of cenopopulations (Fig. 2).

In the overwhelming majority of the plants encountered, the color of all the petals of the corolla is uniform light yellow or turning into a white tint at the edges of the petals, but during our study it was revealed that in some cenopopulations the corolla can be colored differently and unevenly, especially at its keel. Approximately $0.3 \%$ of individu- 


\section{VARIABILITY OF MORPHOLOGICAL CHARACTERISTICS}

als have a light blue or light pink tint of part of the corolla petals and/or the lower part of the keel and/or veins (for example, in C6 and 19), less than $0.07 \%$ have a light magenta or even light purple tint of the veins of the carina, edges of the petals or the whole corolla (Fig. 3).

Table. Average values of morphometric features of $H$. grandiflorum in the southern Volga Upland

\begin{tabular}{|c|c|c|c|c|c|}
\hline \multirow{2}{*}{ Feature* } & \multirow{2}{*}{$X \pm S_{x}$} & \multicolumn{2}{|c|}{ Lim } & \multirow{2}{*}{$\begin{array}{c}C_{v}, \\
\% * *\end{array}$} & \multirow{2}{*}{$\begin{array}{c}I_{p} \\
\text { unit fraction** }\end{array}$} \\
\hline & & $\min$ & $\max$ & & \\
\hline Plant height, $\mathrm{cm}$ & $25.9 \pm 0.97$ & 5.1 & 63.9 & 23.2 & 0.71 \\
\hline Number of leaves, pcs & $22.3 \pm 0.84$ & 9.0 & 34.0 & 29.4 & 0.62 \\
\hline Length of leaves, $\mathrm{cm}$ & $16.9 \pm 0.69$ & 3.0 & 31.8 & 31.6 & 0.73 \\
\hline Number of foliole pairs, pcs & $3.0 \pm 0.17$ & 1.0 & 7.0 & 23.6 & 0.75 \\
\hline Length of unpaired foliole, $\mathrm{cm}$ & $2.1 \pm 0.16$ & 0.7 & 4.6 & 31.3 & 0.78 \\
\hline Width of unpaired foliole, $\mathrm{cm}$ & $1.2 \pm 0.12$ & 0.4 & 3.7 & 31.8 & 0.81 \\
\hline Number of inflorescences, pcs & $5.6 \pm 0.28$ & 2.0 & 18.0 & 26.7 & 0.78 \\
\hline Number of flowers on inflorescence, pcs & $37.2 \pm 1.83$ & 16.0 & 109.0 & 31.5 & 0.61 \\
\hline Length of standard, cm & $2.0 \pm 0.09$ & 1.3 & 2.8 & 10.6 & 0.36 \\
\hline Diameter of caudex, $\mathrm{cm}$ & $1.3 \pm 0.10$ & 1.0 & 1.7 & 21.3 & 0.19 \\
\hline
\end{tabular}

Note. ${ }^{*} n=2560 ; * *$ average for all cenopopulations; $X$ - arithmetic mean; $S_{x}$ - arithmetic mean error; $C_{V}$ - coefficient of variation; $I_{p}$ - coefficient of phytocenotic plasticity.

\section{DISCUSSION}

Comparative analysis of the data obtained indicates the morphological heterogeneity in cenopopulations, which is typical of many plant species: the well-being of the entire population is achieved here with a certain heterogeneity in the sizes of individual plants and in suppressing the growth and size of individual cenopopulations. Decrease in parameters of features, especially plant height and leaf length, in some cases (for example, in cenopopulations 4, $15,16,21,22$ and 23), is most often associated with a higher anthropogenic load in their habitats (grazing, trampling, steppe burns, recreation, littering, collection by the population, etc.), compared with the habitats of other coenotic populations studied. The mean and extremums of individual features do not always coincide in the same cenopopulations.

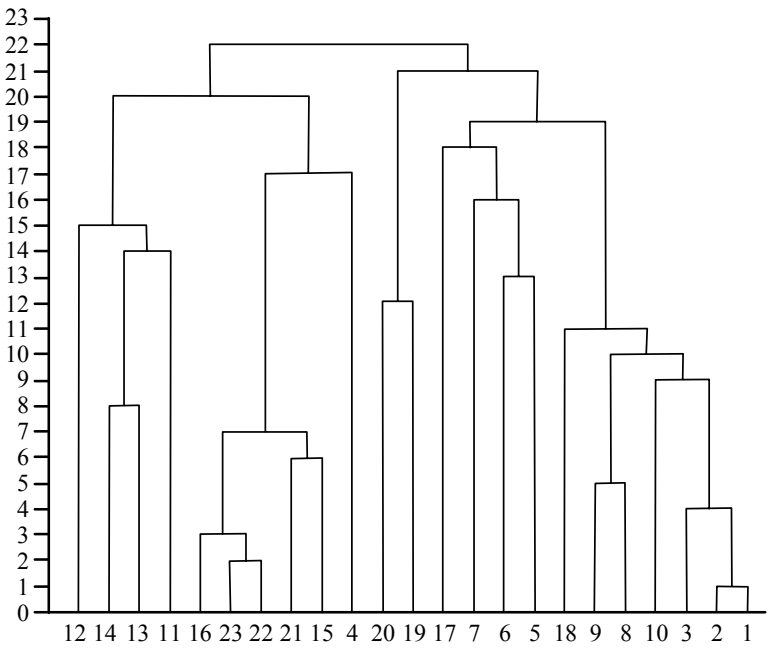

Fig. 2. The similarity groups of the investigated $\mathrm{H}$. grandiflorum cenopopulations by the mean values of the morphological features of the individuals (on the abscissa - the distance of association, on the ordinate - the numbers of cenopopulations) 
Thus, the highest average height of plants is typical for C20 $(36.7 \mathrm{~cm})$, and maximum for C6 $(63.9 \mathrm{~cm})$. In addition, it is noticeable that $H$. grandiflorum has higher values of morphometric parameters in the northeastern part of the study area (Lavrentiev, 2018).

The length of the standard generally has a low level of variability, the diameter of the caudex, the plant height, the number of foliole pairs, the number of inflorescences

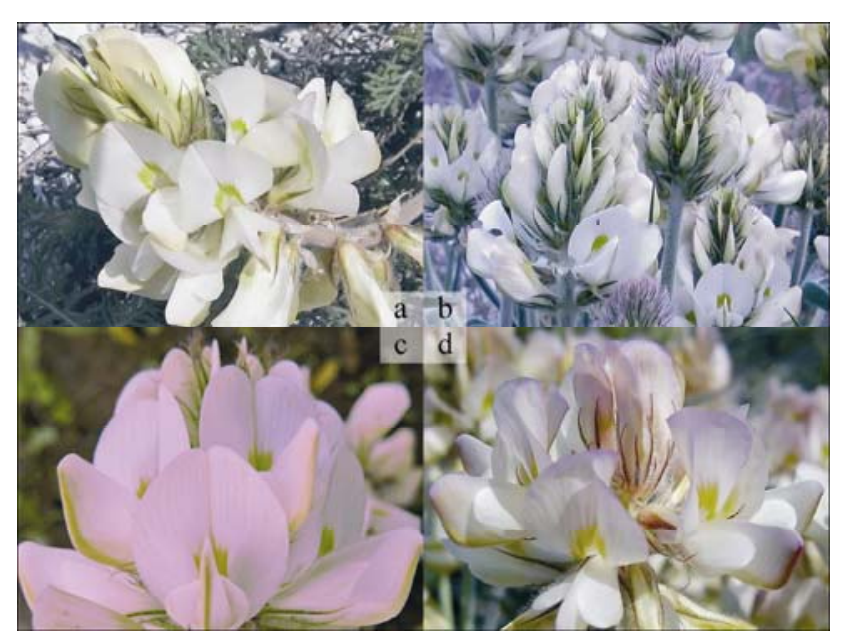

Fig. 3. Color variations corolla $H$. grandiflorum ( $a-$ standard light yellow with a white tint; $b$ - light blue; $c$ - light pink with pink veins; $d$ - light purple at the edges of the petals) and the number of leaves are increased, the length of unpaired foliole, the number of flowers on the inflorescence, the length of the leaves and the width of unpaired foliole are high. However, in some cases (as, for example, in C14), even the length of the standard is quite variable. In differentiation of populations and determination of the species of Hedysarum the features mentioned in the beginning are more suitable than the later ones. The least variable and most informative morphological features $H$. grandiflorum (in descending order of importance) are: the length of the standard, the diameter of the caudex, the plant height, the number of the foliole pairs, the number of the inflorescences, the number of the leaves, the length of the unpaired foliole, the number of flowers on the inflorescence, the length of the leaves and the width of the unpaired foliole.

As we can see from the table, the greatest phytocenotic plasticity in cenopopulations is inherent in the width and the length of the unpaired foliole, the number of the inflorescences and of foliole pairs, length of the leaf and height of the plants, a slightly smaller plasticity can be noted in the number of the leaves and of flowers in the inflorescence, and the smallest one - in the length of the standard and the diameter of the caudex. The main morphometric features of the studied plants correspond to the description of P. S. Pallas (1773). When comparing the obtained data with the factual information from the Orenburg Cisurals (Avdeyev, Ryazanova, 2008), it can be noted that the studied plants are lower $(25.9$ opposite $27.5 \mathrm{~cm}$ ) and their leaf length is more (16.9 opposite 13.3 $\mathrm{cm}$ ), especially in southern cenopopulations, and the number of foliole pairs, length of the standard and variability indicators are similar. Data from other regions (Volgograd, Samara, Lugansk and Belgorod) generally cover the size of the features from the study area (Suprun, Filimonova, 2008; Suprun, Schanzer, 2017).

In total, as a result of cluster analysis, some groups included closely located cenopopulations of $\mathrm{H}$. grandiflorum. The cenopopulations located in the southern part of 


\section{VARIABILITY OF MORPHOLOGICAL CHARACTERISTICS}

the study area (C11-14) (Krasnoarmeysk district) and on the border of the Khvalynsk and Volsk districts (C19 and 20) are clearly distinguished. The third group, which consists of cenopopulations and is described from the northeast of the study area $(\mathrm{Cl}-3,5$ 10,17 and 18) is more complex, which can be associated with a significant diversity in those places of landforms, parent rock material and soils (Lavrentiev, Boldyrev, 2017). The fourth group consists of cenopopulations with recorded higher anthropogenic influences $(\mathrm{C} 4,15,16,21-23)$ and in fact is a component of the first three groups. The changes of features are gradual in individuals throughout the study area (Lavrentiev, 2018). Generalized data analysis suggests that dimensional indicators of individuals of cenopopulations of the species studied depend on the thickness of soil, which decreases from fescue-feather grass to petrophyte steppes.

Similar individuals, whose the corolla can be colored differently and unevenly, are found in other regions, for example, V. I. Avdeyev, A. A. Ryazanova (2008) noted pale violet marginal color of the flower carina in $10-15 \%$ of individuals of $H$. grandiflorum in the Orenburg region. Uniform deep pink color is characteristic of the closely related species $H$. argyrophyllum, and although $\mathrm{C}$. von Ledebour assumed it to be typical of environs of Khvalynsk (Ledebour, 1842) (and this is periodically mentioned in modern publications (Vasyukov et al., 2015)), plants of non standard or uneven colouring of the $H$. grandiflorum in the southern Volga Upland do not belong to $H$. argyrophyllum, since the individuals encountered do not correspond to the morphological features or the uniformity of color or morphometry. Perhaps, some of these individuals belong to the recently described hybrid $H$. $\times$ polychromum $(H$. argyrophyllum $\times H$. grandiflorum $)(\mathrm{Ku}-$ likov, 1998), but most likely these hybrids are typical of the northeastern and eastern regions, where the $H$. argyrophyllum individuals are found close to the Guberlin mountains of the Orenburg region, from which M. S. Knyasev (2013) recently described a neotype. The same applies to other close species $-H$. biebersteinii and the hybrid $H$. $\times$ smirnovii $(H$. biebersteinii $\times$ H. grandiflorum) (Knyasev, 2011), which are found in the southwest of the study area.

There is every reason to believe that the slight deviance of the color of corolla and the variability of most morphometric features is associated with the complex biomorphological heterogeneity of individuals inherent in most species. Formation in the $H$. grandiflorum population of individuals with recessive coloration of the corolla were noted by scientists a long time ago and had already been described as a color variation (for example, $H$. grandiflorum var. violaceum B. Fedtsch.) or less often as a subspecies (for example, $H$. grandiflorum ssp. argenteum B. Fedtsch.).

\section{CONCLUSION}

The variability of most morphological features and the deviance of corolla's colouring in $H$. grandiflorum is associated with complex biomorphological heterogeneity of individuals. Higher morphometric parameters are characteristic of the northeastern part of the study area. Individuals with a recessive colouring of the corolla represent intraspecific colour variations. The variability of morphological features of Hedysarum grandiflorum ranges from low - for generative sphere signs, such as the length of the standard, and to high - for vegetative signs like the plant height, the length of the leaves, the length and width of the unpaired foliole. 
The obtained data can be useful when comparing the morphological features of H. grandiflorum individuals in other parts of the range, the systematics of the genus $\mathrm{He}$ dysarum, refinement taxonomic identity of individual populations, introductions and further research in the field of variability and adaptation of Hedysarum.

\section{REFERENCES}

Abbas Z., Alam J., Khan S. M., Hussain M., Abbasi A. M. Diversity, Ecological Feature and Conservation of a High Montane Flora of the Shigar Valley (Karakorum range) Baltistan Region, Northern Pakistan. Pakistan J. of Botany, 2019, vol. 51, no. 3, pp. 985-1000. DOI: https://doi.org/10.30848/PJB2020-1(11)

Abramova L. M., Mustafina A. N., Karimova O. A., Shigapov Z. H. Structure and State of Populations of Three Rare Species of the Genus Hedysarum (Fabaceae) in the South Urals. Botanicheskii Zhurnal, 2019, vol. 104, no. 5, pp. 729-740. DOI: https://doi.org/10.1134/S0006813619040021

Arigela R. K., Singh R. K. On the Identity of Crotalaria nallamalayana Rasingam \& J. Swamy (Fabaceae). Phytotaxa, 2018, vol. 374, no. 2, pp. 177. DOI: https://doi.org/10.11646/ phytotaxa.374.2.11

Arkhipova E. A., Boldyrev V. A., Bulanaya M. V., Bulany Yu. I., Grebenyuk S. I., Davidenko O. N., Davidenko T. N., Kostetsky O. V., Lavrentiev M. V., Mayevski V. V., Nevskiy S. A., Panin A. V., Reshetnikova T. B., Sedova O. V., Stepanov M. V., Stukov V. I., Khudyakova L. P., Shevchenko E. N., Shilova I. V. Flowering Plant Species to be Included Into the Third Edition of the Red Book of Saratov Region. Izv. Saratov Univ. N. S., Ser. Chemistry. Biology. Ecology, 2016, vol. 16, no. 3, pp. 303-309 (in Russian). DOI: https://doi.org/10.18500/1816-9775-2016-16-3-303-309

Arkhipova E. A., Boldyrev V. A., Lavrentiev M. V., Stepanov M. V. To the Syntaxonomic Composition of Terrestrial Vegetation of the Khvalynsky National Park. In: Natural Heritage of Russia: Collection of Scientific Works. art. International. Scientific. Conf. Penza, Izdatel'stvo Penzenskogo gosudarstvennogo universiteta, 2017, pp. 108-110 (in Russian).

Avdeyev V. I., Ryazanova A. A. Characters Variability of Some Hedysarum L. Species in the Orenburg Preduralye. Izvestiya Orenburg State Agrarian University, 2008, vol. 2, no. 18, pp. 213-216 (in Russian).

Başköse İ., Yaprak A. E., Akyildirim B. Hedysarum ketenoglui (Fabaceae-Hedysareae), a New Species from Southern Turkey. Phytotaxa, 2018, vol. 357, no. 4, pp. 291-297. DOI: https://doi.org/10.11646/phytotaxa.357.4.5

Belous Ya. V., Zinner N. S. Morphobiological Features of Hedysarum alpinum Grown in Conditions of Tomsk Region. International Research J., 2013, vol. 10, no. 17, pp. 91-92 (in Russian).

Bidarlord M., Ghahremaninejad F., Mozafarian V. Hedysarum persicum (Hedysareae, Leguminosae), a New Species from Talesh Mountains, Iran. Phytotaxa, 2015, vol. 234, no. 3, pp. 294-298. DOI: https://doi.org/10.11646/phytotaxa.234.3.11

Dehshiri M. M., Goodarzi M. Taxonomic Notes on Hedysarum sect. Crinifera (Fabaceae) in Iran, with the Description of a New Species. Annales Botanici Fennici, 2016, vol. 53, no. 1-2, pp. 21-26. DOI: https://doi.org/10.5735/085.053.0204

Dural H., Citak B. Y. Morphology and Anatomy of Hedysarum pannosum (Boiss.) Boiss. (Fabaceae). Acta Botanica Croatica, 2015, vol. 74, no. 1, pp. 19-29. DOI: https://doi.org/10.1515/ botcro-2015-0009

Erst A. A., Zheleznichenko T. V., Novikova T. I., Dorogina O. V., Banaev E. V. Ecological and Geographic Variability of Hedysarum theinum and Features of its Propagation in vitro. Contemporary Problems of Ecology, 2014 vol. 7, no. 1, pp. 67-71.

Golovanov Ya. M., Knyazev M. S., Yamalov S. M., Korolyuk A. Yu., Lebedeva M. V. New floristic records from the Orenburg region and some adjacent regions of Russia (the materials of 


\section{VARIABILITY OF MORPHOLOGICAL CHARACTERISTICS}

seasons 2016-2017 expeditions). Turczaninowia, 2018, vol. 21, no. 1, pp. 131-143 (in Russian). DOI: https://doi.org/10.14258/turczaninowia.21.1.12

Haidar A., Qaiser M. Contribution to the Flora of Pakistan: Hedysarum alii and H. shahjinalense spp. nov. (Fabaceae) and Three New Records. Nordic J. of Botany, 2018, vol. 36, no. 7, pp. e01742. DOI: https://doi.org/10.1111/njb.01742

Huang J., Wong K. H., Tay S. V., How A., Tam J. P. Cysteine-Rich Peptide Fingerprinting as a General Method for Herbal Analysis to Differentiate Radix Astragali and Radix Hedysarum. Frontiers in Plant Science, 2019, vol. 10, pp. 973. DOI: https://doi.org/10.3389/fpls.2019.00973

Ilyina V. N. E Kologo-biologicheskie osobennosti i struktura populyacij redkix vidov roda Hedysarum L. v usloviya bassejna Srednej Volgi [Ecologo-Biological Features and Population Structure of Rare Species of the Genus Hedysarum L. in Conditions of the Middle Volga Basin]. Thesis Diss. Cand. Sci. (Biol.). Togliatti, 2006. 19 p. (in Russian).

Ilyina V. N. Vitality and the Vital Structure of the Cenopopulations of Hedysarum grandiflorum Pall. and H. rasoumovianum Fisch. et Helm in the Samara Region. Bulletin Samarskaya Luka, 2005, vol. 16, pp. 179-186 (in Russian).

Karnaukhova N. A. Ontogenesis and Life Forms of Hedysarum L. (Fabaceae) in South Siberia. Contemporary Problems of Ecology, 2015, vol. 8, no. 5, pp. 614-623. DOI: https://doi.org/10.1134/S199542551505008X

Karnaukhova N. A. Anatomo-morphological Features of the Leaves of Hedysarum theinum (Fabaceae) in Western Altai. Contemporary Problems of Ecology, 2016, vol. 9, no. 3, pp. 349354. DOI: https://doi.org/10.1134/S1995425516030057

Karnaukhova N. A., Dorogina O. V., Selyutina I. Yu. The Anatomical Structure of Leaf in Species of Hedysarum L. Sect. Gamotion Basin. in South Siberia. Turczaninowia, 2018, vol. 21, no. 4, pp. 150-160 (in Russian). DOI: https://doi.org/10.14258/turczaninowia.21.4.15

Knyasev M. S. A New Hybrid Species of the Genus Hedysarum (Fabaceae) from the East Europe. Botanicheskii Zhurnal, 2011, vol. 96, no. 8, pp. 1122-1126 (in Russian).

Knyasev M. S. The Review of Eastern European and Some Siberian Species of Hedysarum (Fabaceae). Botanicheskii Zhurnal, 2013, vol. 98, no. 10, pp. 1261-1273 (in Russian).

Kulikov P. V. Floristic Findings in the Southern Ural (Chelyabinsk region). Botanicheskii Zhurnal, 1998, vol. 83, no. 12, pp. 137-145 (in Russian).

Lavrentiev M. V. Botanico-ecological Characteristics of Hedysarum grandiflorum Pall. and Phytocenosis with his Participation in the Southern Volga Upland. In: Research of Young Scientists in Biology and Ecology. Saratov, Izdatel'stvo Saratovskogo universiteta, 2016 a, vol. 14, pp. 38-41 (in Russian).

Lavrentiev M. V. Botaniko-e kologicheskaya xarakteristika Hedysarum grandiflorum Pall. $i$ fitocenozov s ego uchastiem v yuzhnoj chasti Privolzhskoj vozvy shennosti [Botanico-Ecological Characteristics of Hedysarum grandiflorum Pall. and Phytocenoses With His Participation in the Southern part of the Volga Upland]. Diss. Cand. Sci. (Biol.). Saratov, 2018. 197 p. (in Russian)

Lavrentiev M. V. Morphological Variability Hedysarum grandiflorum Pall. in the Southern Volga Upland. In: Biodiversity and Anthropogenic Transformation of Natural Ecosystems: Proceedings of the Russian Scientific-Practical Conference. Saratov, Saratovskii istochnik Publ., 2016 b, pp. 144-147 (in Russian).

Lavrentiev M. V., Boldyrev V. A. Habitat and Adaptation Characterization of Hedysarum grandiflorum Pall. (Fabáceae, Dicotylédones) in the Southern Volga Upland. Povolzhskiy J. of Ecology, 2017, no. 1, pp. 54-61 (in Russian). DOI: https://doi.org/10.18500/1684-7318-2017-1-54-61

Ledebour C. F. Flora Rossica sive, Enumeratio plantarum in totius Imperii Rossici provinciis europaeis, asiaticis et americanis hucusque observatarum. Stuttgartiae, Sumtibus Librariae E. Schweizerbart, 1842, vol. I, pp. 698-708. 
M. V. Lavrentiev, V. A. Boldyrev

Liu P.-L., Wei Y., Wen J., Chang Z.-Y. Recognition of a New Species of Hedysarum (Fabaceae, Hedysareae) from China Based on Morphological and Molecular Evidence. Phytotaxa, 2017, vol. 295, no. 3, pp. 237-245. DOI: https://doi.org/10.11646/phytotaxa.295.3.4

Liu P.-L., Chen X.-L., Lu Y., Chang Z.-Y., Yue M. New Species Discovered from Old Collections, the Case of Hedysarum wangii sp. nov. (Fabaceae, Hedysareae). Phytotaxa, 2019 a, vol. 413, no. 1, pp. 27-38. DOI: https://doi.org/10.11646/phytotaxa.413.1.3

Liu Y., Yang H., Wang W., Liang H., Zhang Q. Chemotaxonomy Studies on the Genus $\mathrm{He}$ dysarum. Biochemical Systematics and Ecology, 2019 b, vol. 86, pp. 103902. DOI: https://doi.org/10.1016/j.bse.2019.05.010

Mamaev S. A. Levels of Variability of Anatomical and Morphological Signs of Pine and Their Variations in Different Climatic Zones. Botanical research in the Urals. Notes of the Sverdlovsk branch of the All-Union Botanical Society, 1970, vol. 5, pp. 15-24 (in Russian).

Maslova N. V., Muldashev A. A., Elizaryeva O. A. Creating Rare Species Artificial Populations of the Genus Hedysarum L. (Fabaceae). IOP Conference Series: Earth and Environmental Science, 2019, vol. 272, no. 2, pp. 022200. DOI: https://doi.org/10.1088/1755-1315/272/2/022200

Nafisi H., Kazempour-Osaloo S., Mozaffarian V., Amini-Rad M. Hedysarum alamutense (Fabaceae-Hedysareae), a New Species from Iran, and its Phylogenetic Position Based on Molecular Data. Turkish J. of Botany, 2019, vol. 43, no. 3, pp. 386-394. DOI: https://doi.org/10.3906/bot$1806-50$

Pallas P. S. Reise durch verschiedene Provinzen des Rußischen Reichs. Zweite Theil. SanktPetersburg, Kayserlische Academie der Wissenschaften, 1773, [4]. 373 S.

Portnyagina N. V., Fomina M. G., Punegov V. V., Zaynullina K. S., Echishvili E. E. The Results of Hedysarum alpinum L. Introduction in Conditions of Middle Taiga Subzone in Komi Republic. Izvestia of Samara Scientific Center of the Russian Academy of Sciences, 2014, vol. 16, no. 1, pp. 796-799 (in Russian).

Red Book of the Russian Federation (Plants and Mushrooms). Moscow, KMK Scientific Press Ltd., 2008. 855 p. (in Russian).

Red Book of the Saratov Region: Mushrooms. Lichens. Plants. Animals. Saratov, Izdatel'stvo Torgovo-promyshlennoi palaty Saratovskoi oblasti, 2006. 528 p. (in Russian).

Suprun N. A., Filimonova E. S. Variability of Morphological Features of the Flower Hedysarum grandiflorum Pall. (Fabaceae). In: Fundamental and Applied Problems of Botany in the Early XXI Century. Materials of the All-Russian Conference. Petrozavodsk, Karelian Research Center RAS Publ., 2008, pp. 332-333 (in Russian).

Suprun N. A., Schanzer I. A. Morphological Variability of Species Hedysarum. Bulletin of Udmurt University, Ser. Biology. Earth Sciences, 2017, vol. 27, no. 1, pp. 51-58 (in Russian).

Syeva S. Ya., Mandaeva S. A. Morphological and Biochemical Characteristics of the Hedysarum neglectum (Fabaceae) in Places of Natural Growth in Republic of Altai. Plant Life of Asian Russia, 2013, vol. 1, no. 11, pp. 13-18 (in Russian).

Tonguç F., Reis M., Tonguç M., Önder S. Morphology, Chemical Composition, and Seed Germination of Hedysarum pogonocarpum Boiss. Propagation of Ornamental Plants, 2019, vol. 19 , no. 1 , pp. 11-17.

Vasyukov V. M., Senator S. A., Rakov N. S., Saksonov S. V. Plants Described from the Right Bank of the Middle Volga. Botanicheskii Zhurnal, 2015, vol. 100, no. 1, pp. 44-59 (in Russian).

Wu W., Zhang D., Tian L., Zhang M., Zhou X. Features of Artificial Plant Communities from the East Sand Region of the Qinghai Lake over the Last 10 years. Acta Ecologica Sinica, 2019, vol. 39, no. 6, pp. 2109-2121. DOI: https://doi.org/10.5846/stxb201712292353

Zhmud E. V. Analysis of Variability of Morphological Features of Some Species of the Family Fabaceae Lindl. in Southern Siberia. Problems of Botany in Southern Siberia and Mongolia: 


\section{VARIABILITY OF MORPHOLOGICAL CHARACTERISTICS}

Collection of Scientific Articles on the Materials of the XII International Scientific-Practical Conference. Barnaul, Kolmogorov I. A. Publ., 2013, pp. 70-72 (in Russian).

Zhmud E. V. Ecological Flexibility Hedysarum gmelinii (Fabaceae) in Altai Mountains and Chakassia. Tomsk State Pedagogical University Bulletin, 2014, vol. 11, no. 2, pp. 220-226 (in Russian).

Zhmud E. V., Dorogina O. V., Achimova A. A. Morphological Plasticity of Hedysarum austrosibiricum B. Fedtsch (Fabaceae) Shoots Under Different Ecological and Geographical Conditions. Contemporary Problems of Ecology, 2018, vol. 11, no. 2, pp. 159-167. DOI: https://doi.org/10.1134/S1995425518020130

Zlobin Yu. A., Sklyar V. G., Klimenko A. A. Populations of Rare Plant Species: Theoretical Bases and Methods of Study. Sumy, University Book Publ., 2013. 439 p. (in Russian).

Zubairova Sh. M. Finding the State of Population Hedysarum daghestanicum Boiss. ex Rupr. Modern Problems of Science and Education, 2015, vol. 3, pp. 564 (in Russian).

Zubairova Sh. M., Anatov D. M. Variability of Morphological Signs in Cenopopulation Hedysarum daghestanicum Rupr. ex Boiss. Izvestia of Samara Scientific Center of the Russian Academy of Sciences, 2012, vol. 14, no. 1, pp. 1735-1737 (in Russian).

Zvyagina N. S., Dorogina O. V., Catalan P. Genetic Relatedness and Taxonomy in Closely Related Species of Hedysarum (Fabaceae). Biochemical Systematics and Ecology, 2016, vol. 69, pp. 176-187. DOI: https://doi.org/10.1016/j.bse.2016.10.001 
M. V. Lavrentiev, V. A. Boldyrev

УДК $581.4+582.736$

\title{
ИЗМЕНЧИВОСТЬ МОРФОЛОГИЧЕСКИХ ПРИЗНАКОВ HEDYSARUM GRANDIFLORUM (FABACEAE, DICOTYLEDONES) В РАЗЛИЧНЫХ ЭКОЛОГИЧЕСКИХ УСЛОВИЯХ ЮЖНОЙ ЧАСТИ ПРИВОЛЖСКОЙ ВОЗВЫШЕННОСТИ
}

\author{
М. В. Лаврентьев, В. А. Болдырев \\ Саратовский национальный исследовательский государственный университет \\ имени Н. Г. Чернышевского \\ Россия, 410012, Саратов, Астраханская, 83 \\ E-mail: mihaillavrentev@yandex.ru
}

Поступила в редакцию 25.02.2019 г., после доработки 17.03.2019 г., принята 21.04.2019 г.

Lavrentiev M. V., Boldyrev V. A. Variability of Morphological Characteristics of Hedysarum grandiflorum (Fabaceae, Dicotyledones) in Various Ecological Conditions of the Southern Volga Upland [Лаврентьев M. В., Болдырев B. А. Изменчивость морфологических признаков Hedysarum grandiflorum (Fabaceae, Dicotyledones) в различных экологических условиях южной части Приволжской возвышенности] // Поволжский экологический журнал. 2019. № 4. C. 445 - 457. DOI: https: https://doi.org/10.35885/1684-7318-2019-4-445-457

В последние десятилетия интерес к изучению Hedysarum только возрастает. Исследователи в своих работах охватывают классические вопросы морфологии и изменчивости внешних признаков Hedysarum grandiflorum и других видов Hedysarum (уточняется морфология, существующие виды более точно разделяются, описывается морфология новых видов, в том числе редких), при этом подробных описаний практически нет. В статье приводятся сведения о морфологии внешних признаков $H$. grandiflorum в южной части Приволжской возвышенности. Исследование проводилось в 2007 - 2018 гг. Были изучены 23 ценопопуляции H. grandiflorum в местообитаниях с различными экологическими условиями, в которых было заложено более 600 учётных площадок, что позволило сделать вывод, согласно которому морфологические признаки H. grandiflorum достаточно вариабельны, при этом значения морфометрических параметров более высокие в северо-восточной части района исследования. Благополучие популяции достигается при некоторой разнородности размеров отдельных особей и при подавлении роста и размеров отдельных ценопопуляций. Уменьшение параметров признаков чаще всего связано с более высокой антропогенной нагрузкой. Размерные показатели особей ценопопуляций исследованного вида зависят от мощности почвы, которая снижается от типчаково-ковыльных до петрофитных степей. Кластерный анализ позволил разделить ценопопуляции на южные, северные, северновосточные и с антропогенным воздействием. Наименее изменчивыми и наиболее информативными морфологическими признаками H. grandiflorum (в порядке уменьшения значимости) являются: длина флага, диаметр каудекса, высота растений, число пар листочков, число соцветий, число листьев, длина непарных листочков, число цветков на соцветии, длина листов и ширина непарных листочков. У подавляющего большинства встреченных растений окраска всех лепестков венчика равномерная светло-желтая или переходящая в белый оттенок на краях лепестков. В некоторых ценопопуляциях венчик может быть окрашен по-разному 


\section{VARIABILITY OF MORPHOLOGICAL CHARACTERISTICS}

и неравномерно, особенно его лодочка. Примерно у $0.3 \%$ особей встречается светло-голубой или светло-розовый оттенок части лепестков венчика и/или нижней части лодочки и/или жилок, у менее $0.07 \%$ - светло-пурпурный или даже светло-фиолетовый оттенок жилок лодочки, краёв лепестков или всего венчика. Подобные особи встречаются и в других регионах. Эти изменения отмечены учёными достаточно давно и уже описывались ранее как цветовая вариация (например, H. grandiflorum var. violaceum) или, реже, как подвид (например, H. grandiflorum ssp. argenteum). Особи с рецессивной окраской венчика из района исследования являются внутривидовыми цветовыми вариациями.

Ключевые слова: Hedysarum grandiflorum, Hedysarum, морфология, изменчивость, окраска венчика, Приволжская возвышенность.

DOI: https://doi.org/10.35885/1684-7318-2019-4-445-457 